\section{(C) OPEN ACCESS}

\title{
Hepatitis B in pregnancy
}

\author{
Jessica Katharine Dyson, ${ }^{1}$ Julia Waller, ${ }^{2}$ Andrena Turley, ${ }^{3}$ Enid Michael, ${ }^{3}$ \\ Samuel Moses, ${ }^{2,4}$ Manoj Valappil, ${ }^{2,4}$ Mark Hudson,, ${ }^{1,4}$ \\ Margaret Bassendine, ${ }^{1,4}$ Stuart McPherson ${ }^{1,4}$
}

\begin{abstract}
${ }^{1}$ Liver Unit, Freeman Hospital, Newcastle upon Tyne Hospitals NHS Foundation Trust, Newcastle upon Tyne, UK ${ }^{2}$ Health Protection Agency, Newcastle upon Tyne, UK ${ }^{3}$ Department of Obstetrics, Royal Victoria Infirmary, Newcastle Upon Tyne Hospitals NHS Trust, Newcastle upon Tyne, UK ${ }^{4}$ Institute of Cellular Medicine, Newcastle University, Newcastle upon Tyne, UK
\end{abstract}

\section{Correspondence to} Dr Jessica Katharine Dyson, Liver Unit, Freeman Hospital, Newcastle upon Tyne Hospitals NHS Foundation Trust, High Heaton, Newcastle upon Tyne NE7 7DN, UK;

jessicadyson@doctors.org.uk

Received 5 July 2013 Revised 21 September 2013 Accepted 25 September 2013 Published Online First 17 October 2013

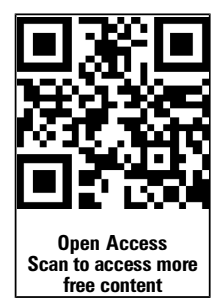

To cite: Dyson JK, Waller J, Turley A, et al. Frontline Gastroenterology 2014:5:111-117.

\begin{abstract}
Objective Vertical transmission of the hepatitis $B$ virus (HBV) is the commonest mode of infection and can be prevented with immunoprophylaxis of the infant and antiviral therapy in the mother. Our aim was to review a cohort of subjects with HBV in pregnancy to determine the prevalence of active disease or high HBV-DNA levels that required treatment to prevent transmission, and to review the management of mothers and infants.
\end{abstract}

Methods A retrospective case-note review was conducted of all the HBV-infected pregnant women and their infants who attended the Newcastle obstetric services from 2007 to 2011. Results There were 113 pregnancies in 81 women (median age 28 years; $15 \%$ hepatitis B e antigen (HBeAg) positive) during 2007-11. $71 \%$ of mothers were first diagnosed with HBV during pregnancy. The mothers were born in 28 different countries. $69 \%$ of mothers had an HBV-DNA level less than $2000 \mathrm{IU} / \mathrm{mL}$ and $13 \%$ had HBV-DNA levels greater than $1.0 \times 10^{7} \mathrm{IU} / \mathrm{mL}$ so would be eligible for antiviral therapy to prevent transmission to the infant. $9 \%$ had active eAg-positive $\mathrm{HBV}$ and $3 \%$ had active eAg-negative HBV requiring treatment. All infants born to $\mathrm{HBeAg}$-positive mothers received hepatitis B immunoglobulin ( $\mathrm{HBIG}$ ) appropriately and $76 \%$ of infants received a full HBV vaccination course. One infant born to an $\mathrm{HBeAg}$-negative mother was hepatitis B surface antigen positive 1 year post-delivery.

Conclusions One in six women had active HBV requiring treatment or high HBV-DNA levels that would benefit from antiviral treatment to reduce the transmission risk. HBIG was administered appropriately but completion of the vaccination course was suboptimal.

\section{INTRODUCTION}

Chronic Hepatitis B virus (HBV) infection affects approximately 400 million individuals worldwide. ${ }^{1-4}$ It is estimated that without therapy $15-40 \%$ of patients will develop serious complications related to chronic HBV including cirrhosis, liver failure and hepatocellular carcinoma, ${ }^{5}$ and there are an estimated 620000 HBV-related deaths each year worldwide. ${ }^{6}$ The worldwide prevalence of chronic HBV infection varies widely, with $8-10 \%$ of the population being affected in high prevalence areas (China, other parts of Asia, sub-Saharan Africa and the Amazon basin). Overall, the UK is an area of low endemicity, with an estimated hepatitis B surface antigen (HBsAg) prevalence of $0.3 \%,{ }^{7}$ but prevalence rates are much higher in individuals migrating from endemic countries. A recent study found that $8.7 \%$ of the British-Chinese and 3.1\% of the Pakistani community of the north east of England were chronically infected with $\mathrm{HBV}^{8}$

Mother to infant (vertical) transmission from an HBV-infected mother is the commonest mode of transmission worldwide and accounts for $50-60 \%$ of chronically infected patients. It is estimated that up to $25 \%$ of these patients die prematurely from the complications of chronic HBV infection in later life (cirrhosis, liver failure, liver cancer). ${ }^{9}{ }^{10}$ The risk of perinatal transmission of $\mathrm{HBV}$ is related to maternal HBV-DNA levels and the hepatitis B e antigen ( $\mathrm{HBeAg}$ ) status of the mother. Without immunoprophylaxis, vertical transmission occurs in $70-90 \%$ if the mother is $\mathrm{HBeAg}$ positive. ${ }^{11}$ This is reduced to $40 \%$ if the mother is $\mathrm{HBeAg}$ negative. ${ }^{12}$ Overall, vertical transmission is reduced to $5-10 \%$ with appropriate active and passive immunoprophylaxis (hepatitis B vaccination for all plus hepatitis B immunoglobulin (HBIG) if the mother is HBeAg positive). However, in infants born to mothers with high HBV-DNA levels, despite immunoprophylaxis $8-32 \%$ of infants develop perinatal infection. ${ }^{13-15}$

In order to reduce perinatal transmission of chronic HBV, antenatal screening 
for HBV was introduced in the UK in 2000 and immunoprophylaxis is given to infants born to HBV-infected mothers. It is recommended that all infants born to $\mathrm{HBV}$-infected mothers should receive HBV vaccination at birth and complete a four-dose course. $^{16}$ Babies born to highly infectious mothers should receive HBIG within $24 \mathrm{~h}$ of delivery as well as active immunisation.

Recent studies have demonstrated that treatment with lamivudine $e^{17} 18$ or telbivudine ${ }^{19} 20$ in the third trimester significantly reduces the risk of transmission in mothers with a high HBV-DNA level. As a result, the British Viral Hepatitis Group (BVHG) and the National Institute for Health and Care Excellence (NICE) recommend treating mothers with an HBV-DNA level greater than $10^{7} \mathrm{IU} / \mathrm{mL}$ with oral antiviral agents in the third trimester to reduce further the risk of transmission. ${ }^{21} 22$

Little is currently known about the demographics of patients with hepatitis B in pregnancy in the UK and what proportion of patients have active disease or who require antiviral treatment in pregnancy to reduce transmission risk. Our aim was to review our cohort of subjects with $\mathrm{HBV}$ in pregnancy to determine the prevalence of active disease or high HBV-DNA levels that require treatment. In addition, our aim was to review the management both of mothers during pregnancy and the mothers and infants postpartum.

\section{METHODS}

This was a retrospective study reviewing the management for all HBV-infected pregnant women who attended the Newcastle obstetric services between 2007 and 2011. This patient review was registered and approved by the hospital clinical audit department. Patients were identified from the obstetric blood-borne virus database that keeps demographic data for all pregnant women who are infected with a blood-borne virus. The medical notes for all HBV-infected pregnant mothers were reviewed and data collected on: patient demographics; HBV, hepatitis C virus, hepatitis delta virus and HIV serology and virology results; biochemical results; management pre and post-delivery and antiviral treatment. When mothers had more than one pregnancy, data about the mothers were collected from the first pregnancy. Medical records of all infants born in 2008-11 (not just first pregnancies) were also reviewed to determine whether HBV vaccination and HBIG were administered appropriately.

The normal range for ALT in our centre is $0-40 \mathrm{IU} /$ L for women.

HBV disease activity was defined into five groups based on European Association for the Study of the Liver (EASL) guidelines 2012: ${ }^{3}$

- The immunotolerant phase with HBeAg positivity, high HBV-DNA, ALT less than $40 \mathrm{IU} / \mathrm{L}$ and no/minimal liver necroinflammation or fibrosis.
- The immune active HBeAg-positive phase with HBV-DNA greater than $20000 \mathrm{IU} / \mathrm{mL}$, elevated or fluctuating aminotransferases (ALT $>40 \mathrm{IU} / \mathrm{L}$ ) and moderate or severe liver necroinflammation or fibrosis (METAVIR A2-3 and/or F2-4).

- The inactive carrier state with low or undetectable viral replication (HBV-DNA <2000 IU/mL), ALT <40 IU/L and no/minimal fibrosis.

- The active HBeAg-negative phase with fluctuating viral replication (HBV-DNA $>2000 \mathrm{IU} / \mathrm{mL}$ ) and aminotransferases (ALT > $40 \mathrm{IU} / \mathrm{L}$ ) with moderate/severe liver inflammation and or fibrosis (METAVIR A2-3 and/or F2-4).

- Indeterminate disease activity patients who had either HBV-DNA greater than $2000 \mathrm{IU} / \mathrm{mL}$ with ALT less than $40 \mathrm{IU} / \mathrm{L}$ or HBV-DNA less than $2000 \mathrm{IU} / \mathrm{mL}$ with ALT greater than $40 \mathrm{IU} / \mathrm{L}$.

\section{RESULTS}

\section{Demographics of the cohort}

There was a total of 113 pregnancies in 81 HBsAg-positive women during the period studied. Eighty (99\%) were referred to the viral hepatitis service. Twenty-one (26\%) women did not attend more than one of their clinic appointments. The median age of the women at first pregnancy was 28 years (range 1840 years). Fifty-eight $(72 \%)$ mothers were first diagnosed with HBV through antenatal screening. The uptake of testing for $\mathrm{HBV}$ is $96 \%$ nationally in the UK, which means the majority of HBV-infected individuals are likely to be identified. ${ }^{23}$ The mothers were born in a total of 28 different countries (figure 1).

\section{Virology and biochemical results}

All women had their $\mathrm{HBeAg} /$ antibody status checked. Twelve subjects (15\%) were $\mathrm{HBeAg}$ positive and anti-HBe negative, 69 (85\%) were $\mathrm{HBeAg}$ negative and $64(79 \%)$ were hepatitis B e antibody (HBeAb) positive. The median ALT level was $18 \mathrm{IU} / \mathrm{mL}$ (range 5-203, IQR 14). A breakdown of the serum ALT levels in the cohort is shown in table 1.

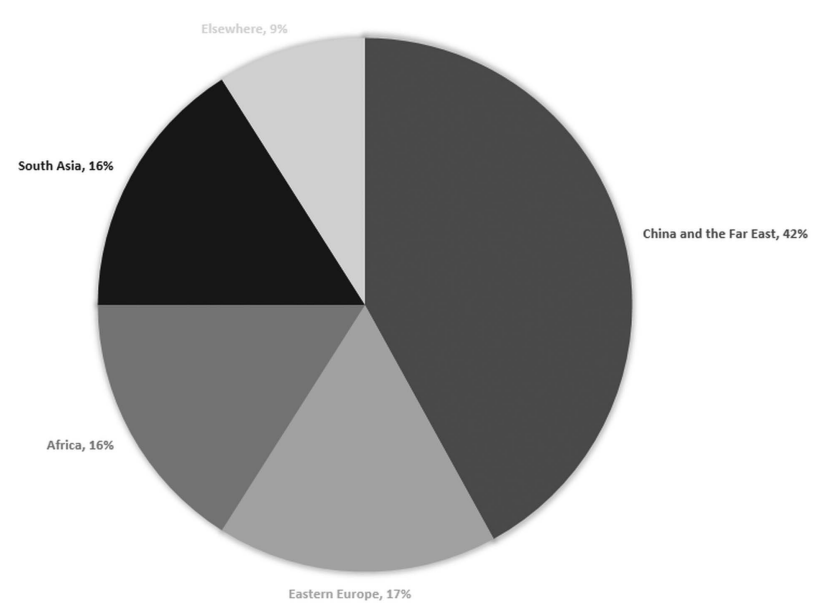

Figure 1 Countries of birth. 
Table 1 Breakdown of the ALT values in the cohort

$<20 \mathrm{IU} / \mathrm{mL}$

$42(54 \%)$

$20-40 \mathrm{IU} / \mathrm{mL}$

$24(31 \%)$

$41-80 \mathrm{IU} / \mathrm{mL}(<2 \times \mathrm{ULN})$

$5(6 \%)$

$>80 \mathrm{lU} / \mathrm{mL}(>2 \times \mathrm{ULN})$

$7(9 \%)$

ULN, upper limit of normal.

Sixty-seven (92\%) patients who attended clinic had their HBV-DNA levels tested during their first pregnancy including all the HBeAg-positive patients. The median HBV-DNA levels was $150 \mathrm{IU} / \mathrm{mL}$ (range $<20$ to $>7.2 \times 10^{8} \mathrm{IU} / \mathrm{mL}, \mathrm{IQR} 7879$ ). Of the patients who had their HBV-DNA tested in pregnancy, 46 (69\%) had an HBV-DNA level less than $2000 \mathrm{IU} / \mathrm{mL}, 12$ (18\%) had HBV-DNA levels between 2000 and $1.0 \times 10^{7} \mathrm{IU} / \mathrm{mL}$ and nine (13\%) had HBV-DNA levels greater than $1.0 \times 10^{7} \mathrm{IU} / \mathrm{mL}$. A breakdown of the patients by disease activity (based on EASL guidelines) is shown in table 2. ${ }^{3}$ If the new 2013 NICE definitions of active HBV (using ALT cut-off of $19 \mathrm{IU} / \mathrm{mL}$ ) were used, $11(92 \%)$ of the HBeAg-positive patients and four $(7 \%)$ of the HBeAg-negative patients would be characterised as having active HBV.

Two patients were co-infected with HIV. One patient was hepatitis $\mathrm{C}$ virus antibody positive but RNA negative and three patients were hepatitis delta antibody positive, but RNA negative. Nine (13\%) women had HBV-DNA levels greater than $1.0 \times 10^{7} \mathrm{IU} / \mathrm{mL}$ so would have been eligible for antiviral treatment in the third trimester of pregnancy to reduce the risk of vertical transmission according to the BVHG and NICE guidelines. $^{21} 22$ If a lower threshold of $2 \times 10^{5} \mathrm{IU} / \mathrm{mL}$ was used for treatment to prevent transmission of HBV to the infant, $12(18 \%)$ would have been eligible to receive antiviral therapy. Two patients received antiviral therapy with tenofovir during pregnancy. One woman co-infected with HIV was started on Truvada (emtricitabine and tenofovir) and Kaletra (lopinavir and ritonavir) at 24 weeks' gestation with a viral load of $1.7 \times 10^{8} \mathrm{IU} /$ $\mathrm{mL}$. The viral load dropped to $4.5 \times 10^{5} \mathrm{IU} / \mathrm{mL}$ on treatment but rose again due to poor compliance and

Table 2 A breakdown of the mothers by HBV disease activity ${ }^{3}$

\begin{tabular}{lllll}
\hline Phase of disease & Number & $\begin{array}{l}\text { eAg } \\
\text { status }\end{array}$ & $\begin{array}{l}\text { Viral load } \\
(\mathrm{IU} / \mathrm{mL})\end{array}$ & $\begin{array}{l}\text { ALT } \\
(\mathrm{IU} / \mathrm{mL})\end{array}$ \\
\hline Immunotolerant & $6(9 \%)$ & $+\mathrm{ve}$ & High & $<40$ \\
Immune active & $6(9 \%)$ & $+\mathrm{ve}$ & $>20000$ & $>40$ \\
HBeAg +ve & & & & $<40$ \\
Inactive carrier & $42(63 \%)$ & $-\mathrm{ve}$ & $<2000$ & $>40$ \\
Active HBeAg -ve & $2(3 \%)$ & $-\mathrm{ve}$ & $>2000$ & \\
Indeterminate & $11(16 \%)$ & & $\begin{array}{l}\text { Either viral load } \\
\end{array}$ \\
& & & $>2000$ with ALT \\
& $<40$ or viral load & \\
& & $<2000$ with ALT & \\
& & $>40$ & \\
\hline
\end{tabular}

HBeAg, hepatitis B e antigen; HBV, hepatitis B virus. treatment was stopped. One woman was started on tenofovir in the third trimester due to high viral load $\left(1.8 \times 10^{8} \mathrm{IU} / \mathrm{mL}\right)$ to reduce the risk of transmission.

\section{Postpartum}

Of those with inactive HBV, $23 \%$ had a postpartum flare in their ALT (defined as greater than or equal to doubling of baseline ALT or rise in ALT to $>40 \mathrm{IU} / \mathrm{mL}$ ). The highest ALT was $52 \mathrm{IU} / \mathrm{mL}$. All patients settled spontaneously. There was no rise in the viral load associated with the increase in ALT for any of the women.

There were six women with eAg-positive immunoactive chronic HBV. Four were not treated as their ALT normalised (three genotype B, one genotype C). Two of them underwent a Fibroscan as a surrogate marker for fibrosis (results 3.8 and $5.1 \mathrm{kPa}$ ) (table 3).

\section{Care of infants}

Data were available for infants born from 2008 to 2011. From a total of 99 pregnancies, data were available for $76(77 \%)$ infants. All 15 infants born to HBeAg-positive mothers were given HBIG at birth. Fifty-eight $(76 \%)$ infants received a full vaccination course and $14(19 \%)$ received three doses. Only 35 $(55 \%)$ of the 64 infants who should have had their post-vaccination status checked to date have had this completed. Thirty-four (97\%) had an adequate response to vaccination with anti-HBs levels greater than $10 \mathrm{IU} / \mathrm{mL}$. One infant (who only received three vaccinations) is $\mathrm{HBsAg}$ positive with a viral load of $5.4 \times 10^{3} \mathrm{IU} / \mathrm{mL}$. The mother was HBeAg negative and $\mathrm{HBeAb}$ positive with a viral load of $1.7 \times 10^{3} \mathrm{IU} / \mathrm{mL}$.

Of the nine infants born to women with HBV-DNA greater than $1 \times 10^{7} \mathrm{IU} / \mathrm{mL}$, all received HBIG appropriately and a full four-dose course of vaccination. Eight infants had their post-vaccination serology testing and all of them had an adequate response to the vaccine.

\section{DISCUSSION}

The present study represents a 'real life' experience of the management of patients with hepatitis B in pregnancy in the UK. A key finding of the study was that more than one in six of the patients seen had active HBV requiring treatment or had high HBV-DNA levels and would benefit from antiviral treatment to reduce the risk of transmission to the infant. This emphasises the importance of ensuring that all HBV-positive mothers are seen during the pregnancy by a team experienced in the management of patients with viral hepatitis. In our cohort, the majority (99\%) of HBV-infected pregnant women are referred to tertiary hepatitis services. However, a high proportion did not attend appointments and efforts to improve attendance need to be intensified. In the present study, we did not explore the reason for non-attendance at appointments, but it is likely that a major reason is the language barrier as a high proportion of patients with HBV have 
Table 3 Patients with active disease who received treatment

\begin{tabular}{lllllll}
\hline Disease activity & Genotype & $\begin{array}{l}\text { ALT } \\
(\mathrm{IU} / \mathrm{mL})\end{array}$ & $\begin{array}{l}\text { Viral load } \\
(\mathrm{IU} / \mathrm{mL})\end{array}$ & Fibroscan result (kPa) & Liver biopsy (METAVIR) & Treatment \\
\hline eAg +ve active CHB & C & 81 & $1.7 \times 10^{8}$ & 4.2 & A1 F1 & Pegasys IFN postpartum \\
eAg +ve active CHB & C & 119 & $1.7 \times 10^{8}$ & 16.3 & A3 F4 & Tenofovir postpartum \\
eAg -ve active CHB & C & 203 & $3.7 \times 10^{5}$ & 5.1 & A2 F1 & Tenofovir postpartum \\
eAg -ve active CHB & E & 122 & $1.9 \times 10^{4}$ & 9.1 & & Tenofovir postpartum \\
\hline
\end{tabular}

$\mathrm{CHB}$; $\mathrm{eAg}$, e antigen; IFN, interferon.

migrated to the UK and English is not their native tongue. It is therefore essential that $\mathrm{HBV}$-infected mothers receive appropriate education about $\mathrm{HBV}$ on diagnosis.

The WHO have recommended global vaccination against hepatitis B since 1992. In the UK there is no universal vaccination programme for $\mathrm{HBV}$, but all mothers are offered screening for HBV (and HIV) during pregnancy. The risk of developing chronic $\mathrm{HBV}$ is related to age at the time of infection, with the highest rates in individuals acquiring the infection perinatally (up to $90 \%$ develop chronic infection). ${ }^{24-}$ ${ }^{27}$ High serum HBV-DNA levels and HBeAg positivity are the most important risk factors for perinatal transmission of HBV to an infant. UK guidelines recommend that all infants born to HBV-infected mothers are vaccinated against $\mathrm{HBV}$ at birth to reduce transmission risk. In addition, $\mathrm{HBIG}$ is given to $\mathrm{HBeAg}$-positive mothers or HBeAg-negative mothers with HBV-DNA levels greater than $1.0 \times 10^{6} \mathrm{IU} / \mathrm{mL}$ as they are at highest risk of transmission. ${ }^{16}$ However, immunoprophylaxis fails to prevent transmission of HBV to the infant in $8-32 \%$ of cases and the majority of these occur in mothers with high serum HBV-DNA levels. ${ }^{13-}$

${ }^{15}$ Randomised controlled trials have demonstrated that perinatal transmission can be significantly reduced by treating mothers with a high viral load with oral antiviral agents (lamivudine or telbivudine) in pregnancy. The first study by $\mathrm{Xu}$ et $a l^{28}$ showed that, in addition to immunoprophylaxis, treatment with lamivudine from week 32 of pregnancy to 4 weeks postpartum in mothers with HBV-DNA levels greater than $2 \times 10^{8} \mathrm{IU} /$ $\mathrm{mL}$ significantly reduced infant $\mathrm{HBsAg}$ seropositivity rates compared with immunoprophylaxis alone $(18 \%$ vs $39 \%$, respectively). More recently $\operatorname{Han}$ et $a l^{19}$ showed that telbivudine treatment starting between weeks 20 and 32 of pregnancy in mothers with HBV-DNA levels greater than $2 \times 10^{6} \mathrm{IU} / \mathrm{mL}$ reduced transmission from $8 \%$ to $0 \%$. In that study all infants also received HBV vaccination and HBIG as is current practice in the UK. Currently, the BVHG recommend treating mothers with a HBV-DNA level of over $1.0 \times 10^{7} \mathrm{IU} / \mathrm{mL}$ with oral antiviral medications in the third trimester to reduce the risk of transmission to infants. $^{21}$ In the present study only two patients received treatment with tenofovir during pregnancy. This was mainly due to the fact that part of the study period pre-dated the BVHG recommendations being introduced in 2008. Five of the nine eligible women were pregnant before the implementation of the guidelines. The other two women who were eligible for treatment after the introduction of the guidelines were treated postpartum (one with interferon and one cirrhotic woman with tenofovir). Our study does indicate that $13 \%$ of mothers seen would be eligible to receive antiviral treatment for this indication. NICE guidelines recommend the use of tenofovir, over lamivudine and telbivudine in pregnancy as tenofovir is a more potent drug and has less propensity to cause resistance. ${ }^{22} 29-31$ In addition, tenofovir has been used extensively in patients with HIV and a registry of over 1000 pregnant mothers exposed to tenofovir has demonstrated no increase in birth defects compared to a control population. ${ }^{32}$

The optimum maternal serum HBV level for the recommendation of antiviral treatment in pregnancy to prevent perinatal transmission is not yet clearly established. However, there is increasing evidence that the risk of vertical transmission remains high with viral loads greater than $2 \times 10^{5} \mathrm{IU} / \mathrm{mL}$ so it may be appropriate to institute treatment at lower HBV-DNA levels to prevent transmission. ${ }^{33}{ }^{34}$ A Chinese study retrospectively assessed a cohort of HBV mothers whose infants were all given immunoprophylaxis with vaccination and HBIG to determine immunoprophylaxis failure rates according to maternal serum HBV-DNA levels. In that study there was a significant positive relationship between immunoprophylaxis failure rates and maternal HBV-DNA levels (0\%, $3.2 \%, 6.7 \%$ and $6.7 \%$ for viral loads of $<6,6-6.99$, $7-7.99,>8 \quad \log _{10}$ copies $/ \mathrm{mL}$, respectively). ${ }^{35}$ Therefore, all failures in that study were in mothers with HBV-DNA levels greater than $2 \times 10^{5} \mathrm{IU} / \mathrm{mL}(>6$ $\log _{10}$ copies $/ \mathrm{mL}$ ), which suggests that a lower HBV-DNA threshold than is currently recommended by the BVHG and NICE guidelines for the treatment of pregnant mothers might be more appropriate, but this requires further evaluation in a controlled trial. $^{21} 22$ If the threshold of over $2 \times 10^{5} \mathrm{IU} / \mathrm{mL}$ was used to recommend antiviral treatment in pregnancy then $18 \%$ of our cohort would have been eligible for treatment. Interestingly though, the one immunoprophylaxis failure in our study occurred in a mother whose HBV-DNA level was $1.7 \times 10^{3} \mathrm{IU} / \mathrm{mL}$, which is well below recommended thresholds for antiviral treatment. Clearly, transmission of HBV can occur in 
utero, intrapartum or postpartum and the mechanism of transmission in this case is not known. ${ }^{36}$

In this study, four (5\%) women were treated postpartum for active disease. Interestingly, this rate was higher than a previous study from Birmingham, UK, in which only $1 \%$ of postpartum women had active disease requiring treatment. The reason for this is not clear as the patient demographics in both studies were similar. ${ }^{37}$ Of note, if the new NICE definitions of active disease were used (ALT $>19 \mathrm{IU} / \mathrm{mL}$ ) then more of our patients $(92 \%$ of $\mathrm{HBeAg}$ positive and $7 \%$ of HBeAg negative) would be eligible for treatment if the ALT remained persistently elevated.

In the present study, $71 \%$ of the mothers were first diagnosed with $\mathrm{HBV}$ in pregnancy, which suggests that a large proportion of patients with $\mathrm{HBV}$ are undiagnosed in our population. A recent case finding study of more than 1000 individuals in the north east of England using dry blood spot testing found that $8.7 \%$ of the British-Chinese and 3.1\% of the Pakistani community had undiagnosed HBV, including individuals with active disease requiring treatment. ${ }^{8}$ In order to address this issue, recent NICE guidelines (UK) have recommended case finding in primary care for individuals at increased risk of $\mathrm{HBV}^{38}$ which it is hoped will lead to the early diagnosis and treatment of HBV.

In the present study HBIG was administered appropriately to the infants at highest risk of vertical transmission of HBV. However, completion of the four-dose HBV vaccination in infants was suboptimal postpartum (76\% completed the full course) and postvaccination testing was inadequate $(55 \%)$. While we clearly need to improve these figures, they compare favourably with a study assessing HBV vaccination uptake in London, which found only $49 \%$ of infants received a full vaccination course and 33\% of infants have post-vaccination testing. ${ }^{39}$

As a result of this review of our practice the Health Protection Agency is now collecting data prospectively on all infants born to HBV-positive mothers. This will improve the accuracy of the information recording for this patient group and ensure that administration of the complete vaccination course is given to all infants. Currently, family doctors are responsible for the administration of vaccinations and post-vaccination testing. A central 'reminder system' has now been introduced to advise family doctors 2 weeks before each vaccination dose is due. If infants still do not receive their vaccination a nominated health visitor will investigate further to ensure it is completed appropriately. Many infants do not have follow-up serology taken to determine whether they have acquired HBV and whether the vaccination has been successful in producing anti-HBsAb. In part this might be due to the need for a blood sample being drawn from the baby, which can be distressing for the infant, mother and phlebotomist. In order to address this, dry blood spot testing has been introduced, which we think will be a more acceptable method of obtaining blood from the infant and should lead to increased testing rates. Dry blood spot testing is a well validated method for HBsAg, anti-hepatitis B core antibody and anti-HBsAb testing. ${ }^{40} 41$

In conclusion, the present study shows that a high proportion of mothers with $\mathrm{HBV}$ in pregnancy have high HBV-DNA levels or active disease and would therefore benefit from treatment to prevent transmission of $\mathrm{HBV}$ to their infant or disease progression. It is therefore essential that all HBV-positive mothers are thoroughly assessed during pregnancy to determine whether they need treatment.

\section{What is already known in this topic?}

Mother to infant (vertical) transmission is the commonest mode of Hepatitis B transmission worldwide.

- The risk of transmission is highest in HBeAg positive mothers and those with high HBV DNA.

- The risk of vertical transmission is reduced to $5-10 \%$ with active and passive immunoprophylaxis.

- Antiviral therapy in the 3rd trimester reduces transmission risk in mothers with high HBV DNA levels (>1×107 IU/ML).

\section{What this study adds?}

- More than 1 in 6 women had active disease or high HBV DNA levels and would benefit from antiviral treatment to reduce the transmission risk or treat active hepatitis.

- Hepatitis B Immunoglobulin was administered appropriately to reduce transmission risk.

- There was suboptimal completion of the vaccination course and follow-up serology testing in infants.

- Attendance at hepatitis clinic appointments was poor.

How might it impact on clinical practice in the foreseeable future?

- All Hepatitis B positive pregnant women should be referred to viral hepatitis services for assessment.

- Efforts to improve attendance at hepatitis clinic appointments need to be intensified.

- Our procedure for delivering the vaccination course and post-vaccination testing of infants has changed to ensure this is completed.

Contributors JKD and SMP devised the project, collected and analysed the data, wrote the manuscript and managed the 
patients. JW was instrumental in data collection. AT and EM assisted in patient identification and data collection. SM, MV, $\mathrm{MH}$ and $\mathrm{MB}$ reviewed the manuscript and managed the patients.

Ethics approval This patient review was registered and approved by the hospital clinical audit department.

Patient consent Not required.

\section{Competing interests None.}

Provenance and peer review Not commissioned; externally peer reviewed.

Open Access This is an Open Access article distributed in accordance with the Creative Commons Attribution Non Commercial (CC BY-NC 3.0) license, which permits others to distribute, remix, adapt, build upon this work noncommercially, and license their derivative works on different terms, provided the original work is properly cited and the use is non-commercial. See: http://creativecommons.org/licenses/by$\mathrm{nc} / 3.0 /$

\section{REFERENCES}

1 Cooke GS, Main J, Thursz MR. Treatment for hepatitis B. BMJ 2010;340:b5429.

2 Lok AS, McMahon BJ. Chronic hepatitis B: update 2009. Hepatology 2009;50:661-2.

3 European Association for the Study of the Liver. EASL clinical practice guidelines: management of chronic hepatitis B virus infection. J Hepatol 2012;57:167-85.

4 McMahon BJ. Epidemiology and natural history of hepatitis B. Semin Liver Dis 2005;25(Suppl. 1):3-8.

5 Bosch FX, Ribes J, Cleries R, et al. Epidemiology of hepatocellular carcinoma. Clin Liver Dis 2005;9:191-211.

6 Goldstein ST, Zhou F, Hadler SC, et al. A mathematical model to estimate global hepatitis B disease burden and vaccination impact. Int J Epidemiol 2005;34:1329-39.

7 Hahne S, Ramsay M, Balogun K, et al. Incidence and routes of transmission of hepatitis B virus in England and Wales, 19952000: implications for immunisation policy. J Clin Virol 2004;29:211-20.

8 McPherson S, Valappil M, Moses SE, et al. Targeted case finding for hepatitis $B$ using dry blood spot testing in the British-Chinese and South Asian populations of the North-East of England. J Viral Hepat 2013;20:638-44.

9 Beasley RP, Hwang LY, Lin CC, et al. Hepatocellular carcinoma and hepatitis B virus. A prospective study of 22707 men in Taiwan. Lancet 1981;2:1129-33.

10 McMahon BJ, Alberts SR, Wainwright RB, et al. Hepatitis B-related sequelae. Prospective study in 1400 hepatitis B surface antigen-positive Alaska native carriers. Arch Intern Med 1990;150:1051-4.

11 Beasley RP, Trepo C, Stevens CE, et al. The e antigen and vertical transmission of hepatitis B surface antigen. Am J Epidemiol 1977;105:94-8.

12 Alter MJ. Epidemiology of hepatitis B in Europe and worldwide. J Hepatol 2003;39(Suppl. 1):S64-9.

13 Wiseman E, Fraser MA, Holden S, et al. Perinatal transmission of hepatitis B virus: an Australian experience. Med J Aust 2009;190:489-92.

14 van Zonneveld $M$, van Nunen $A B$, Niesters HG, et al. Lamivudine treatment during pregnancy to prevent perinatal transmission of hepatitis B virus infection. J Viral Hepat 2003;10:294-7.

15 Xiao XM, Li AZ, Chen X, et al. Prevention of vertical hepatitis $\mathrm{B}$ transmission by hepatitis $\mathrm{B}$ immunoglobulin in the third trimester of pregnancy. Int J Gynaecol Obstet 2007;96:167-70.

16 Department of Health. Green Book: Immunisation against infectious disease. The Stationery Office, 2006. http://www. gov.uk/government/uploads/system/uploads/attachment_data/ file/206232/Green-Book-updated-070513.pdf

17 van Nunen AB, de Man RA, Heijtink RA, et al. Lamivudine in the last 4 weeks of pregnancy to prevent perinatal transmission in highly viremic chronic hepatitis B patients. J Hepatol 2000;32:1040-1.

18 Shi Z, Yang Y, Ma L, et al. Lamivudine in late pregnancy to interrupt in utero transmission of hepatitis B virus: a systematic review and meta-analysis. Obstet Gynecol 2010;116:147-59.

19 Han GR, Cao MK, Zhao W, et al. A prospective and open-label study for the efficacy and safety of telbivudine in pregnancy for the prevention of perinatal transmission of hepatitis B virus infection. J Hepatol 2011;55:1215-21.

20 Pan CQ, Han GR, Jiang HX, et al. Telbivudine prevents vertical transmission from $\mathrm{HBeAg}$-positive women with chronic hepatitis B. Clin Gastroenterol Hepatol 2012;10:520-6.

21 British Viral Hepatitis Group. BVHG Consensus StatementUK guidelines for the management of babies born to women who are HBsAg positive. 2008. http://www.basl.org.uk/ uploaded_files/Provision $\% 20$ of $\% 20$ antiviral $\% 20$ services.pdf

22 Sarri G, Westby M, Bermingham S, et al. Guideline Development Group. Diagnosis and management of chronic hepatitis B in children, young people, and adults: summary of NICE guidance. BMJ 2013;346:f3893.

23 Health Protection Agency. Data Tables for the National Antenatal Infections Screening Monitoring (NAISM) Programme Surveillance Update. 2011.

24 Edmunds WJ, Medley GF, Nokes DJ, et al. The influence of age on the development of the hepatitis B carrier state. Proc Biol Sci 1993;253:197-201.

25 Hyams KC. Risks of chronicity following acute hepatitis B virus infection: a review. Clin Infect Dis 1995;20:992-1000.

26 McMahon BJ, Alward WL, Hall DB, et al. Acute hepatitis B virus infection: relation of age to the clinical expression of disease and subsequent development of the carrier state. J Infect Dis 1985;151:599-603.

27 Stevens CE, Neurath RA, Beasley RP, et al. HBeAg and anti-HBe detection by radioimmunoassay: correlation with vertical transmission of hepatitis B virus in Taiwan. J Med Virol 1979;3:237-41.

$28 \mathrm{Xu} \mathrm{WM}$, Cui YT, Wang L, et al. Lamivudine in late pregnancy to prevent perinatal transmission of hepatitis B virus infection: a multicentre, randomized, double-blind, placebo-controlled study. J Viral Hepat 2009;16:94-103.

29 van Bommel F, Wunsche T, Mauss S, et al. Comparison of adefovir and tenofovir in the treatment of lamivudine-resistant hepatitis B virus infection. Hepatology 2004;40:1421-5.

30 van Bommel F, Zollner B, Sarrazin C, et al. Tenofovir for patients with lamivudine-resistant hepatitis B virus (HBV) infection and high HBV DNA level during adefovir therapy. Hepatology 2006;44:318-25.

31 Woo G, Tomlinson G, Nishikawa Y, et al. Tenofovir and entecavir are the most effective antiviral agents for chronic hepatitis B: a systematic review and Bayesian meta-analyses. Gastroenterology 2010;139:1218-29.

32 APRSC. Antiretroviral pregnancy registry international interim report for 1 Jan 1989-31 January 2012. In: Committee APRS, ed. http://www.APRegistry.com: Wilmington, NC: Registry Coordinating Center, 2012. 
33 Ngui SL, Andrews NJ, Underhill GS, et al. Failed postnatal immunoprophylaxis for hepatitis B: characteristics of maternal hepatitis B virus as risk factors. Clin Infect Dis 1998;27:100-6.

34 del Canho R, Grosheide PM, Mazel JA, et al. Ten-year neonatal hepatitis B vaccination program, The Netherlands, 1982-1992: protective efficacy and long-term immunogenicity. Vaccine 1997;15:1624-30.

35 Zou H, Chen Y, Duan Z, et al. Virologic factors associated with failure to passive-active immunoprophylaxis in infants born to HBsAg-positive mothers. J Viral Hepat 2012;19:e18-25.

36 Mufti AR, Reau N. A pregnant patient with a positive hepatitis B surface antigen. Frontline Gastroenterol 2013;4:12-19.

37 Bhattacharya S, O’Donnell K, Dudley T, et al. Ante-natal screening and post-natal follow-up of hepatitis B in the West Midlands of England. QJM 2008;101:307-12.
38 National Institute for Health and Care Excellence. PH43 Hepatitis B and C-ways to promote and offer testing. 2012. http://www.nice.org.uk/nicemedia/live/14003/61863/ 61863.pdf

39 Giraudon I, Permalloo N, Nixon G, et al. Factors associated with incomplete vaccination of babies at risk of perinatal hepatitis B transmission: a London study in 2006. Vaccine 2009;27:2016-22.

40 Tappin DM, Greer K, Cameron S, et al. Maternal antibody to hepatitis B core antigen detected in dried neonatal blood spot samples. Epidemiol Infect 1998;121:387-90.

41 Brown BS, Klapper PE, Guiver M. Development of diagnostic serological and molecular screening from diired blood spots for HCV, HIV, HBV and syphilis. J Clin Virol 2009;44(Suppl. 1): S27-S8. 